\title{
Nasal Expulsion of Taenia saginata: A Case Report
}

\author{
Ayşe Karaaslan, Yasemin Akın, Mustafa Özçetin, Melis Bayram Şirinoğlu, \\ Serap Genç Yüzüak, Yetkin Ayhan, Mehmet Alay
}

Department of Pediatrics, Kartal Dr. Lütfi Kırdar Training and Research Hospital, İstanbul, Turkey

Submitted: 17.11.2015 Accepted: 07.10.2016

Correspondence: Yasemin Akın Kartal Dr. Lütfi Kırdar Eğitim ve Araştırma Hastanesi, Çocuk Sağlığ ve Hastalıkları Kliniği, İstanbul, Turkey

E-mail: jasminetr@hotmail.com

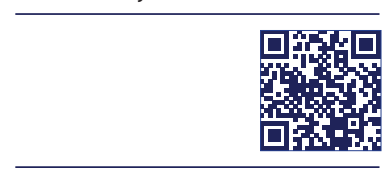

Keywords: Child; nasal expulsion; Taenia saginata.

\begin{abstract}
Taenia saginata is one of the species of intestinal tapeworms for which humans are the only definitive hosts. It occurs worldwide; however, it emerges mostly where the consumption of improperly cooked beef is common. Most human carriers are asymptomatic, and patients who are symptomatic may sense the movement of proglottids through the anus. Other associated symptoms are nausea, epigastric pain, and anorexia. The diagnosis is usually established by macroscopic determination and microbiological tests. Praziquantel and niclosamide are the therapeutic agents for the treatment. This study aimed to report a case of a 4-yearold boy, in which T. saginata proglottids were expelled through the nose and anus.
\end{abstract}

\section{INTRODUCTION}

Taenia saginata is a human parasite that can be seen all over the world. However, is more common in European and Asian regions where uncooked meat is usually consumed. T. saginata eggs or pregnant proglottids are exposed to the external environment through human feces and infect cattle by staying alive for days or even months. The oncospheres hatch in the cattle gut, invade the intestinal wall, and migrate to muscles in a hematogenous way. They become fluid-filled cysts called cysticercus in the muscles and can reach to $5-10 \mathrm{~mm}$ in size in $3-4$ months. The infection starts with the consumption of improperly cooked meat that contains cysticercus. ${ }^{[1]}$ Most people carrying adult cestodes are asymptomatic, but they may also have clinical symptoms such as epigastric pain, nausea, headache, urticaria, and excretion of proglottids in the stool. In this study, a case of a 4-year-old boy with T. saginata was presented with the nasal expulsion of $T$. saginata, which is seen rarely.

\section{CASE REPORT}

A 4-year-old boy visited the outpatient clinic with the complaint of expulsion of moving, white-colored lesions, 4-5 cm length, from his nose and feces in the last 6 months (Figure I). He stated that he used a parasite-killer agent containing albendazole a few times, but his complaints were not resolved. He had no complaints other than this clinical symptom. His clinical history revealed that he ate raw soudjouk often. No pathological signs were found in the physical examination of the child who was $14.5 \mathrm{~kg}(10-25 \mathrm{p})$ and $100 \mathrm{~cm}$ (10-25p). His clinical or family history showed no features. Other members of his family had no similar complaints. His laboratory analyses revealed the following: leukocyte, 7100/ $\mathrm{mm}^{3}$; hemoglobin, II.I g/dL; mean corpuscular volume, 75.7; thrombocyte, $320,000 / \mathrm{mm}^{3}$; eosinophil, $500 / \mathrm{mm}^{3}$; the other biochemical values, including total serum iron level and total iron binding capacity, were within normal limits. His chest $x$-ray and abdominal ultrasonography were reported as normal. His physical examination was normal; no 


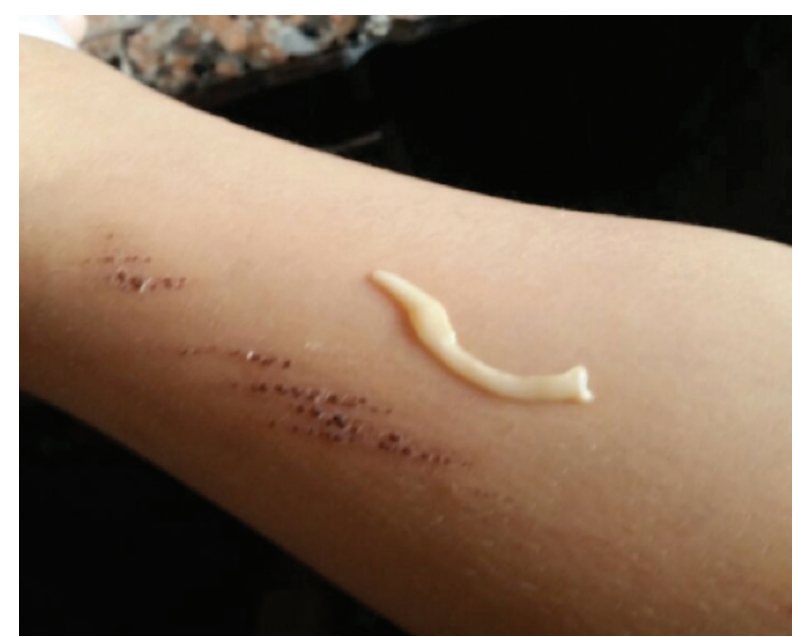

Figure 1. A T. saginata proglottid expelled from the nose.

abdominal sensitivity or urticarial rash was detected. During his examinations, several moving, white-opaque worm-like lesions appeared from his nose. Since some of these lesions were 5- to 6-cm-long worm-like structures with two sharp ends, it was thought that some of these lesions might be Ascaris lumbricoides as believed by previous physicians. However, a microbiological analysis was planned by considering the treatment resistance before repeating the associated treatment. These lesions were identified as $T$. saginata proglottid in the analysis using the microscopic method. Niclosomide treatment was administered in a single dose. $\mathrm{He}$ also excreted four taenias through the anus, the longest one being $1 \mathrm{~m}$ and others being $60-70 \mathrm{~cm}$ in length. His complaints were not repeated in the following days.

Consent was obtained from the patient who participated in this study.

\section{DISCUSSION}

Tapeworms, also known as intestinal taenias, are of two main types: T. saginata and Taenia solium. Besides these two types, another type called Taenia asiatica is also found in several countries such as Taiwan, China, and Vietnam. ${ }^{[2]}$ Like other tapeworms, T. saginata is a human parasite. It has not been detected in any organism other than in adult human being. The source of the infection is undercooked beef, and the cattle are intermediate hosts. An adult $T$. saginata is usually shorter than $5 \mathrm{~m}$; however, it can reach up to $25 \mathrm{~m}$ in length. ${ }^{[3]}$ For an adult taenia, an average of six proglottids can be excreted through feces per day. Each proglottid has almost 100,000 eggs that are excreted through feces and infect the cattle. After this intermediate host phase that can continue for years, humans get infected again due to the consumption of undercooked striated muscles of cattle, which contain cysticercus reaching a size of about $\mathrm{I} \mathrm{cm}$.

Most patients carrying tapeworms have no symptoms.
A sensation of moving proglottids in the anus or observing proglottids on underwear and/or stool may be the only symptom. Moreover, patients can experience several symptoms such as epigastric pain, nausea, vomiting, headache, anxiety, and urticaria. It is unlikely that the parasite moves to other areas due to tight intestinal wall adhesion or inhibitory effect of gastric acidity. However, it has been shown in the literature that they may require surgical interventions due to obliterations in appendices or biliary or pancreatic ducts. ${ }^{[4-6]}$ Sheikh et al. reported that a 6.3-m-long $T$. saginata was released from the nose of a female patient. ${ }^{[7]}$ In the present case, T. saginata proglottids were released from the patient's nose and anus. The parasite might have moved to the nose because it was not tightly attached to the intestinal wall or not sufficiently inhibited by gastric acidity. Sheikh et al. stated that nasal expulsion was a rather rare path. ${ }^{[7]}$

The diagnosis of tapeworms can be made by detecting their eggs in stool, but this method is not sufficient to identify distinct tapeworm species. However, T. saginata and $T$. solium can be distinguished by morphological identification of proglottids in stool samples. In T. saginata, proglottids have 12 or more uterine branches, while in $T$. solium, this number is less than 10 . Scolexes usually do not appear in stool samples before tapeworms die. However, different tapeworm species can be identified by looking at different scolex structures after treatment. T. saginata has four different lateral absorbent organs in the scolex but no hook, whereas T. solium has absorbent organs as well as double lines of hooks. Laboratory assistants should be careful not to infect themselves from tapeworm eggs. [8] Currently, enzyme-linked immunosorbent assay and polymerase chain reaction methods are used to increase diagnostic sensitivity and detecting DNA of $T$. saginata, respectively. ${ }^{[9]}$ Laboratory analyses reveal I5\% eosinophils. Since some lesions in the present case at the time of visit were 5- to 6-cm-long worm-like structures with two sharp ends, it was thought that some of these lesions might be Ascaris lumbricoides. Since the patient in this case did not recover despite treatment with albendazole several times and the lesions were diagnosed as T. saginata proglottids microbiologically, the final diagnosis was $T$. saginata. It was believed that the lesions might have taken this shape when they were expelled from the nasal cavity. The eosinophil detection in this patient also supported the diagnosis.

Praziquantel is the first medical intervention in treating the tapeworm infection. It is sufficient to apply a single dose $(5-10 \mathrm{mg} / \mathrm{kg})$ for a complete cure. ${ }^{[10]}$ Niclosamide (chewable tablets) is an alternative treatment strategy when praziquantel is not accessible; I g niclosamide should be used in children weighing $1 \mathrm{I}-34 \mathrm{~kg}$ and $1.5 \mathrm{~g}$ in children weighing more than $34 \mathrm{~kg} .{ }^{[3]}$ Since praziquantel is not accessible in Turkey, niclosamide was used to treat the patient. The anamnesis provided by the patient family 
indicated that the patient passed four taenias on the same day after the treatment. All complaints of the patient were resolved after the treatment.

T. saginata is a human parasite that occurs because of eating undercooked beef. Although these organisms are excreted from the body through the anus, they may become asymptomatic by excretion through other routes such as nose. Moreover, it should be kept in mind that they may be in a form similar to that of Ascaris, unlike flat pasta. Therefore, the microbiological analysis should be requested in the therapy-resistant cases such as the present one.

Authorship contributions

Concept: A.K.; Design: A.K.; Data collection \&/or processing: M.Ö., Y.A., M.A.; Analysis and/or interpretation: Y.A.; Literature search; M.B.Ş., S.G.Y.; Writing: A.K.; Critical review: M.Ö., Y.A.

Conflict of interest

None declared.

\section{REFERENCES}

1. Korkmaz M. Barsak helmintleri. ANKEM Derg 2006;20:170-6.

2. Hoberg EP. Phylogeny of Taenia: Species definitions and origins of human parasites. Parasitol Int 2006;55:23. [CrossRef]

3. Uptodate.-http://0210c6zov.y.http.www.uptodate.com/contents/ intestinal-tapeworms? source $=$ search_result $\&$ search $=$ taenia + saginat a\&selected Title $=1 \sim 7$.

4. Karanikas ID, Sakellaridis TE, Alexiou CP, Siaperas PA, Fotopoulos AC, Antsaklis GI. Taenia saginata: a rare cause of bowel obstruction. Trans R Soc Trop Med Hyg 2007;101:527-8. [CrossRef]

5. Liu YM, Bair MJ, Chang WH, Lin SC, Chan YJ. Acute pancreatitis caused by tapeworm in the biliary tract. Am J Trop Med Hyg 2005;73:377-80

6. Hakeem SY, Rashid A, Khuroo S, Bali RS. Taenia saginata: A Rare Cause of Gall Bladder Perforation. Case Rep Surg 2012;2012:572484.

7. Sheikh M, Sheikh I, Ali I, Reshi F. Nasal expulsion of Taenia Saginata: a rare route of expulsion. Internet J Surgery 2008;16:1-4.

8. Craig P, Ito A. Intestinal cestodes. Curr Opin Infect Dis 2007;20:524-32.

9. Nunes CM, Lima LG, Manoel CS, Pereira RN, Nakano MM, Garcia JF. Fecal specimens preparation methods for PCR diagnosis of human taeniosis. Rev Inst Med Trop Sao Paulo 2006;48:45-7. [CrossRef]

10. Pawłowski ZS. Efficacy of low doses of praziquantel in taeniasis. Acta Trop 1990;48:83-8. [CrossRef]

\section{Burundan Çıkan Taenia Saginata: Olgu Sunumu}

İntestinal şeritler olarak da adlandırılan Taenia saginata, zorunlu insan paraziti olan bir sestoddur. Çiğ et ve türevlerinin sık tüketildiği ülkeler başta olmak üzere tüm dünyada görülebilir. Çoğu hasta semptomsuz olmakla birlikte semptomu olan hastalar anüsden proglottidlerin hareketini hissedebilirler, diğer ilişkili semptomlar arasında bulantı, epigastrik ağrı ve anoreksi sayılabilir. Tanısı, makroskobik olarak gözlemlenmesi ve mikrobiyolojik yöntemlerle konmaktadır. Tedavisinde 'praziquantel' veya 'niclosamide' kullanılmaktadır. Bu yazıda, T. saginata proglottidlerini burnundan ve anüsünden çıkarma şeklinde klinik bulgu veren dört yaşındaki erkek olgu sunuldu.

Anahtar Sözcükler: Burun çıkış yolu; çocuk; Taenia saginata. 